\title{
Materiality of Mid-Century Modern Furniture in Turkey*
}

\author{
Türkiye'de Yüzyıl Ortası Modern Mobilyanın Materyalliği
}

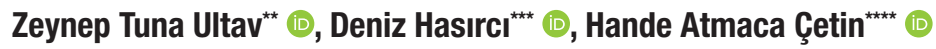

\begin{abstract}
The modern interior emerged as a complex phenomenon, an interchange of modernity and its materiality. One of the constituent elements of this complexity is the progressive relationship with technology. This paper explores the materiality of furniture in terms of its material qualities, production technologies, craft component and inefficacies. The paper focuses on mid-century modern furniture in Turkey as a unique example in the history of furniture design, especially in terms of materiality. In order to understand the material qualities of this historical context, oral history provided a vital methodological tool to uncover the philosophy behind production, contemporary conditions and the designers' personal experiences through their own words. This enables the study to add significantly to the limited knowledge about modern furniture and especially materials in Turkey. The analysis is divided into three parts: materials, production technologies and difficulties. By investigating the material qualities of a furniture piece, the study extends beyond mere forms or styles to cultural productions that narrate the country's efforts to develop and thrive. In addition, it reveals the evolution of both materials and manufacturing techniques. Finally, by connecting these stories to specific furniture pieces, this study documents furniture not just as an artefact but also as the final product of an assemblage of people, materials, and techniques.
\end{abstract}

\section{Keywords}

Modern furniture in Turkey, mid-century, furniture history, oral history, furniture materials, design

\section{Öz}

Bu makale mobilyaların önemini, malzeme nitelikleri, üretim teknolojileri, zanaat bileşenleri ve zorlukları açısından araştırmaktadır. Makalede, mobilya tasarımı tarihinde, özellikle de materyal odaklı içerik açısından eşsiz bir örnek olarak, Türkiye'nin yüzyıl ortası modern mobilyaları incelenmektedir. Bu tarihî bağlamın maddi niteliklerini anlamak için sözlü tarih, üretim, çağdaş koşullar ve tasarımcıların kişisel deneyimlerinin arkasındaki felsefeyi kendi sözleriyle ortaya çıkarmak üzere çok önemli bir metodolojik araç sağlamış ve çalışmanın, modern mobilyalar ve özellikle Türkiye'deki malzemeler hakkındaki sınırlı bilgiye önemli ölçüde katkıda bulunmasına olanak vermiştir. Çalışma, üç bölüme ayrılmıştır: Malzemeler, üretim teknolojileri ve zorluklar. Çalışma, bir mobilya örneğinin maddi niteliklerini araştırmak suretiyle, formların veya stillerin

* This article is an outcome of the Scientific Research Project [A1308001/BAP-A024-K] supported by İzmir University of Economics.

** Correspondence to: Zeynep Tuna Ultav (Assoc. Prof. Dr.), Yaşar University, Faculty of Architecture, Department of Interior Architecture and Environmental Design, Izmir, Turkey. E-mail: zeynep.tunaultav@yasar.edu.tr ORCID: 0000-0003-0478-7333

*** Deniz Hasırcı (Prof. Dr.), İzmir University of Economics, Faculty of Fine Arts and Design, Department of Interior Architecture and Environmental Design, İzmir, Turkey. E-mail: deniz.hasirci@ieu.edu.tr ORCID: 0000-0001-9928-6077

****Hande Atmaca Çetin (Asst. Prof. Dr.), İzmir University of Economics, Faculty of Fine Arts and Design, Department of Interior Architecture and Environmental Design, İzmir, Turkey. E-mail: hande.atmaca@ieu.edu.tr ORCID: 0000-0003-2664-0228

To cite this article: Tuna Ultav, Zeynep, Hasirci, Deniz \& Atmaca Cetin, Hande. "Materiality of Mid-Century Modern Furniture in Turkey." Art-Sanat, 15(2021): 347-367. https://doi.org/10.26650/artsanat.2021.15.0014 
ötesinde, ülkenin kalkınma ve gelişme çabalarını anlatan kültürel üretimlere uzanmakta ayrıca hem malzemelerin hem de üretim tekniklerinin gelişimini ortaya koymaktadır. Son olarak, bu hikâyeleri belirli mobilya örneklerine bağlayarak mobilyaları sadece bir eser olarak değil, aynı zamanda insan, malzeme ve teknikler bütününün sonuç ürünü olarak belgelemektedir.

Anahtar Kelimeler

Türkiye'de modern mobilya, yüzyıl ortası mobilya tarihi, sözlü tarih, mobilya malzemeleri, tasarım

\section{Genisletilmis $\ddot{O ̈ z e t}_{\text {et }}$}

Modernite kapsamında iç mekânın maddeselliği, modernlik tanımının karmaşıklığını yansıtmaktadır. Bu karmaşıklığın kurucu ögelerinden biri ise teknolojiyle ilerleyen ilişkidir. Yirminci yüzyılda, oldukça dinamik değişkenliklerle şekillenen materyallik kavramı, mobilya alanını da etkilemiştir.

Bu makalede, mobilyanın önemini tartışmak amacıyla mobilya, malzeme nitelikleri, üretim teknolojileri, zanaat bileşenleri ve zorlukları açısından araştırılmaktadır. Çalışmada ayrıca, mobilya tasarımı tarihinde, özellikle de materyal odağında eşsizliğiyle, Türkiye'de üretilmiş yüzyıl ortası modern mobilyaları; malzemeler, üretim teknolojileri ve zorluklar başlıkları altında incelenmektedir. Bu tarihî bağlamın maddi niteliklerini anlamak için daha önce belgelenmemiş ve orijinal kaynaklardan mikro geçmişleri bir araya getirmeye ve farklı kültürlere ses vererek tarihin batı ve batı dışı ikilemlerinden farklı bir perspektiften algılanmasını sağlamaya yardımcı olan sözlü tarih yöntemi, üretim, çağdaş koşullar ve tasarımcıların kişisel deneyimlerinin arkasındaki felsefeyi kendi sözleriyle ortaya çıkarmak üzere çok önemli bir metodolojik araç sağlamıştır. Bu yöntem, çalışmanın modern mobilyalar ve özellikle Türkiye'deki malzemeler hakkındaki sınırlı olan bilgiye önemli ölçüde katkıda bulunmasına olanak vermiştir.

Verileri elde etmek için tasarımcılar, zanaatkârlar veya akrabaları ile görüşülmüştür. Görüşülen altı tasarımcı, içmimarlık eğitimi almıştır: Sadun Ersin, Yıldırım Kocacıklıoğlu, Önder Küçükerman, Bediz Koz, Babür Kerim İncedayı ve Yavuz Irmak. Vefat etmiş dört tasarımcının üç akrabasıyla görüşme gerçekleştirilmiştir: Baki Aktar'ın (iç mimar) oğlu mimar Sadık Aktar, Sadi Öziş'in (sanatçı, heykeltıraş) oğlu mimar Neptün Öziş ve Danyal Çiper'in (mimar) yeğeni Arıl Cansel. Son olarak dört zanaatkâr veya yakınları ile görüşmeler yapılmıştır: Mehmet İrfan Dolgun, Mustafa Plevne, Metin Atabey Ata'nın oğlu Erol Ata ve Minas Boyacıyan'ın oğlu Artun Boyacıyan. Materyal doğrudan gözlem yoluyla anlaşılabilse de görüşmelerden elde edilen mikro tarihler, Türkiye'deki mobilyanın hikâyesine katkı sağlayarak mevcut kayıtlı bilgileri zenginleştirmiştir.

Türkiye'nin en öne çıkan malzemelerinden biri olan ve mobilyada kullanımı malzemenin dürüstlügü ile yakından ilintili olan masif ahşap, tüm görüşmeciler tarafindan 
özellikle belirtilmiştir. Benzer şekilde Erol Ata, özellikle 1960 yılına kadar sentetik malzemeler yerine yalnızca masif ahşap gibi doğal malzemelerin kullanıldığından bahsetmektedir. SiM Mobilya Fabrikası (SIMM Mobilya) firmasının (1957) kurucusu Mehmet İrfan Dolgun'un da belirttiği gibi, yüzyıl ortası Türkiye'de sadece birkaç yıl dayanabilecek düşük kaliteli malzemeler bulunmaktaydı. Ancak zamanla malzeme ve üretim kalitesi artmış; bu dönemde ahşap üretim süreçleri ve teknolojisi gelişmezken, Türk mobilyasında metal işçiliğinde önemli gelişmeler yaşanmıştır. Irmak'a göre, metal levhalar daha ucuz olduğu ve seri üretilebildiği için, 1960'lı yıllarda Türkiye'de metal mobilya, çoğunlukla ofis mobilyaları üretiminde yaygınlaşmış; Masis ve Arma gibi şirketler ilk seri üreticiler olarak ortaya çıkmıştır. Bununla birlikte, ahşap mobilyalar, daha yüksek iş pozisyonlarındaki yüksek sosyal sınıf müşterilerin ofisleri için talep görmüştür. Türkiye'de formika üretimi ve daha sonra yonga levhalar sektörün ilerlemesini müjdelemiş̧; formika çok geçmeden Türkiye'de yoğun şekilde kullanılmaya başlanmıştır.

Yüzyıl ortalarında Türkiye'de üretim daha çok zanaatkârın yeteneklerine ve mevcut malzemeye bağlı olarak küçük atölyelerde el üretimine dayalı tekniklere dayanmaktaydı. Bu atölyeler çoğunlukla, eğitimin uygulamalı deneyim yoluyla verildiği bir usta-çırak ilişkisi içinde düzenlenmekteydi. Zanaatkârların çoğu gayrimüslimdi ve geleceğin üreticilerini ilk yetiştirenlerdi. Sınırlı uzmanlık ve malzeme, yaratıcı çözümler gerektirdiğinden, üretilen mobilyaların kalitesi o zamanlar çoğunlukla zanaatkârlığa bağlıydı. Türk çıraklar kalfalık kazandıkça atölyeleri yürütmeye başlamışlar, böylece üretim el yapımı veya bireysel olarak kalmıştır. Seri üretim ise, zamanla en önemli konulardan biri hâline gelmiştir. Irmak, Türkiye'de seri üretimin metal mobilyalarla başladığını, Aktar ise Moderno'nun özellikle yeni makinelerin geliştirilmesiyle seri üretime geçiş yapan lider şirketlerden biri olduğunu belirtmektedir.

Türkiye'de yüzyıl ortası modern mobilya üretimindeki zorlukları; malzemeler, teknoloji, literatür kaynakları, üretim alanı ve personeldeki çeşitli sınırlamalardan kaynaklanan zorluklar olarak tanımlamak mümkündür. Tasarımcılar da teknolojik sınırlamalarla engellenmiştir. Personel ve üretim alanlarıyla ilgili sınırlamalar kapsamında, atölyelerde bir veya iki zanaatkârla çalışıldığı için üretim süreci çok yavaş ilerlerken, mekân koşulları da üretim kalitesini etkilemiştir.

Sonuç olarak, bir ürünün materyalliği konusunda inceleme yapmak, mikro tasarım tarihinin bir ülkenin ekonomik, kültürel ve toplumsal durumundaki gelişmelerle bağlantılı olarak okunmasına izin vermektedir. Dahası, bir mobilya parçasının malzeme niteliklerini anlamak, sadece formlara veya stillere değil, aynı zamanda kültürel üretimlere de dayalı sonuçlar ortaya koyarak, Türkiye'nin gelişme süreci ve çabalarının hikâyesini anlatmaktadır. Malzemeleri, uzmanlık veya teknolojideki sınırlamaların kapsamını kavramak; mobilyaların okunmasını değerli kılar. Doğal, sentetik ve ya- 
ratıcı olmak üzere üç malzeme kategorisinin bu çalışmada sunulmuş olan hikâyesi, malzemelerin hem farklı kullanımlarını açıklamakta hem de daha önce belgelenmemiş tasarımcıları, üreticileri ve firmaları ön plana çıkartmaktadır. Türk tasarım tarihine bu katkının yanı sıra, bu çalışma, malzeme ve üretim tekniklerinin evrimini ortaya koymaktadır. Dahası, hikâyeleri belirli mobilya parçalarına bağlayarak, mobilya yalnızca bir eser olarak değil, aynı zamanda bir insan, malzeme ve teknik topluluğunun sonuç ürünü olarak da belgelenebilir.

Bu çalışmada aktarılmış olan sözlü tarih, Türkiye'deki modern mobilya hakkındaki bilgi birikimine önemli ölçüde katkı sağlamayı amaçlamaktadır. Modern mobilyada kullanılan malzemelerin hikâyesi, Türkiye'ye özgü malzeme ve üretim tekniklerinin belgelenmesini sağlamıştır. Bu çalışma, yirminci yüzyılın ortalarında Türkiye' de geleneksel ahşap mobilya yapım yöntemlerinden yeni malzeme ve tekniklere dönüşümünü kültürel ve materyal modernleşme aracı olarak açıklamaktadır. Türk tasarımcılar, el üretimi ve sınırlı malzemeler kullanarak, sahip oldukları kısıtlı olanaklarla mobilya üretmeye çalışmışlardır. Bu sınırlamalar, bir endüstrinin büyümesine ve bu deneylerden ders çıkarmasına yol açmıştır. Dolayısıyla bu çabalar, Türkiye'de modern mobilyanın önemi konusundaki farkındalığın geliştirilmesi yoluyla dünya düzenine uyum sağlamanın ve uluslararası arenaya katılmanın yolları olarak okunabilir. 


\section{Introduction}

Etymologically, materiality denotes "the quality or state of being material."' Materials ease the perception of reality through their materiality and by making thoughts tangible. ${ }^{2}$ Zumthor values materiality putting forward the infinite options provided only through a single material. ${ }^{3}$ Beyond the definition of materiality as the physical quality/matter; materials have also the potential to stimulate "a sense of weightlessness, archetype, nostalgia or feeling"' . According to Baudrillard, materials diverge in terms of quality; however, they are cultural symbols as part of an integrated system. ${ }^{5}$

The interchange of modernity with the materiality of modern interiors reflects the complexity of modernity. One of the constituent elements of this complexity is the progressive relationship with technology. As Verghese states, "materiality was driven by the dynamic age of change and transformation in the twentieth century". 6

More specifically, furniture is one of the elements that constitute the complexity of the modern interior. This paper explores the materiality of furniture in terms of its material qualities, production technologies, craft component and inefficacies. The paper focuses on midcentury modern furniture in Turkey as a unique example in the history of furniture design, especially in terms of materiality.

In Turkey, mobile furniture was introduced as part of the Western space layout. Such furniture first appeared in palaces as the Ottoman Empire westernised during 19th century before spreading to homes in Istanbul. ${ }^{7}$ İsmail Hakk1 Oygar, summarised the transformation of space making and furniture during early Republican Era in his article entitled New Decorative Arts by stating: "Interior furniture design is the art of the present rather than the past; although people have always used furniture to dec-

1 "Materiality," accessed 19 September 2020, https:/www.merriam-webster.com/dictionary/materiality.

2 Thomas Schröpfer, Material Design: Informing Architecture by Materiality (Basel: Birkhäuser, 2011.$), 8$.

3 Zumthor as cited in Russel Gagg, Iç Mimarlıkta Doku+Malzeme [Basics Interior Architecture 05: Texture + Materials] (İstanbul: Literatür Yayınları, 2012.)

4 Shun Ping Pek, "Exploration of Materiality in Furniture Design," accessed 14 April 2020, https://r.ntu.edu.sg/handle/10356/63316.

5 Baudrillard 1996 as quoted in Demet Arslan Dinçay, "İç Mekân Tasarımında Malzeme ve Mekânda Anlam İlişkisi," accessed 14 April 2020, https://yapidergisi.com/ic-mekan-tasarimininda-malzeme-ve-mekanda-anlam-iliskisi/

6 George Verghese, “Architectural Heritage: Providing a Sense of Place Material Matters in a Modern Interior" (Paper presented at An Interdisciplinary Conference on Issues of Design Education, Business and Material Culture, Toronto, October 12-15, 2005).

7 Oya Boyla, “Mobilya,” Eczacıbaşı Sanat Ansiklopedisi (İstanbul: YEM Yayınları, 1997), 1285-1286. For further information about the change of furniture culture from late Ottoman period to mid-century, please see Meltem Özkaraman Şen, “Türkiye'de 1800-2004 Yılları Arasındaki Değişim Süreci Içinde Tasarımı Etkileyen Faktörler: Ve Bir Örnek Olarak Mobilya Üretimi Modeli” (PhD. dissertation, Mimar Sinan Fine Arts University, 2004) and Serpil Durmuş, “Türkiye’de Modern Mobilyanın Gelişimi” (M.A. thesis, Marmara University, 2005). 
orate their homes, they had never placed this much importance on this form of art in such a communal way."

To understand the material qualities of this historical context, this study adopted the methodology of oral history. This vital tool for investigating beyond the formal features of design products to uncover the philosophy behind production, contemporary conditions and the designers' personal experiences through their own words. Oral history helps to bring together micro-histories from previously undocumented and original sources; it enables history to be perceived from a different perspective than the Western and non-Western dichotomies by giving voice to different cultures. To obtain the data, designers, artisans or their relatives were interviewed. The six interviewed designers all had an interior architecture education: Sadun Ersin (1930- ), Yı1dırım Kocacıklığlu (1937-2015), Önder Küçükerman (1939- ), Bediz Koz (1936), Babür Kerim İncedayı (1945- ) and Yavuz Irmak (1950- ). Three relatives of four deceased designers were also interviewed: Sad1k Aktar, the architect son of Baki Aktar (interior architect) (1920-1978), Neptün Öziş, the architect son of Sadi Öziş (artist, sculptor) (1923-2012), and Ar1l Cansel (PhD), the nephew of Danyal Çiper (architect) (1932-2008). Finally, four artisans or their relatives were interviewed: Mehmet İrfan Dolgun (1928-2019), Mustafa Plevne (1930- ), Erol Ata, the son of Metin Atabey Ata (1934-2018) and Artun Boyaciyan, the son of Minas Boyaciyan (1930-2008). Although material can be understood through direct observation, the micro-histories gathered from the interviews enriched existing formal information by providing additional connections that contributed to the story of furniture in Turkey.

\section{Looking into the Material Development of Mid-Century Modern Furniture through Oral History}

The data on modern furniture collected through oral history method is conveyed in three major categories in this paper. The first category is "Materials," which discusses the transition from natural materials to synthetics, local production and imports and the interchange of material and furniture making. The latter, "Production Technologies," discusses the changes in building furniture and the transition from crafts to industrialised manufacturing. Lastly under the title "Difficulties," the issues stemming from the limitations in materials and technologies specific to the period are discussed. This part is also framed around creative solutions and new possibilities that emerged within limited conditions.

8 Oygar 1932 as quoted in Şebnem Uzunarslan, "Cumhuriyetin İlk Yirmi Yılında Mimarlık Alanındaki Gelişmelerin Mekân ve Mobilyaya Yansımaları," Cumhuriyetin Mekanları / Zamanları / Insanları (Ankara: Dipnot Yayınları, 2010), 169-186. 


\title{
1.1. Materials
}

The analysis is divided into three parts based on the quality of the material: natural, synthetic and creative materials. This division into natural (wood, metal) and synthetic (plastics) materials also follows a progressive timeline. Wood, one of the oldest materials used by man, is regarded as an excellent material for furniture construction since it has been utilised by craftspeople for thousands of years; and metals are valued as aspirational. ${ }^{9}$ Natural materials were a more easily obtainable primary resource in mid twentieth-century Turkey whereas synthetic materials emerged as the country's production methods improved and it gradually opened its doors to imports. ${ }^{10}$ Creative materials emerged between these two periods through efforts to diversify production to overcome the lack of materials. ${ }^{11}$

As one of the most prominent materials in Turkey, solid wood was highlighted by all interviewees as a furniture material. "We used wood, massive wood and plywood". ${ }^{12}$ Its use was also related to the issue of the honesty of materials. Similarly, Ata mentioned using only natural materials like solid boards and laths instead of synthetic materials, especially until 1960. ${ }^{13}$ Ar1l Cansel recalled that his uncle, architect Danyal Çiper, had a keen interest in using only natural and best-quality wood, which he sometimes blended with metal components and steel frameworks. However, his preference was for natural materials like leather and stone, avoiding composite materials or glass on surfaces. ${ }^{14}$ On the other hand, designers also used chipboard or MDF. According to Sadik Aktar, the son of interior architect Baki Aktar, who co-founded the renowned design firm Moderno (1953-1966), MDF was far less known than chipboard, and only became widespread in the early 2000s:

\begin{abstract}
"Today, in furniture manufacturing, chipboard or MDF is commonly used. Solid wood is less used. However, when we look back in history, more precious woods like walnut or mahogany were more commonly used, and there were not ready-made materials like chipboard. While manufacturing such wood, less precious wood was put between them. Later, chipboard and flakeboard were employed. I do not know whether Moderno
\end{abstract}

9 Chris Lefteri, "Traditional Materials," Designing Interior Architecture (Basel: Birkhauser Verlag GmbH, 2013), 157-175; Karla Nielson and David Taylor, Interiors (New York: McGraw-Hill Education, 2006), 232.

10 Within the historical perspective of the subject, Özkaraman Şen explains that in till mid-19 $9^{\text {th }}$ century, even wood as a raw material for furniture production was imported. Özkaraman Şen, "Türkiye'de 1800-2004 Yılları Arasındaki Değişim Süreci İçinde Tasarımı Etkileyen Faktörler: Ve Bir Örnek Olarak Mobilya Üretimi Modeli," 294. In early republican period, with the "Industry Incentives Law" (Teşvik-i Sanayi Kanunu), importing furniture materials started being replaced by local materials where possible. Serpil Durmuş, "Türkiye'de Modern Mobilyanın Gelişimi," 29.

11 The limited possibilities of raw material as well as production can be related to the post-war constraints in Turkey. Özkaraman Şen, “Türkiye’de 1800-2004 Yılları Arasındaki Değişim Süreci İçinde Tasarımı Etkileyen Faktörler: Ve Bir Örnek Olarak Mobilya Üretimi Modeli,” 297.

12 Yavuz Irmak, interview by authors, February 19, 2014.

13 Erol Ata, interview by authors, November 27, 2013.

14 Ar1l Cansel, interview by authors, November 25, 2013. 
reached this standard of manufacturing materials process or not. Chipboard or similar materials were new or did not even exist then." 15

Finding good quality dry wood was difficult while chipboard was very hard to find. In addition, as Mehmet İrfan Dolgun, the founder of SIM Mobilya Fabrikası firm (SIMM Furniture Factory) (1957) points out, they were low quality materials that would last only a couple of years. Consequently, he received many complaints when the armchairs he produced all broke later. Over time, however, the quality of materials and production improved. ${ }^{16}$ As Yavuz Irmak explains, plywood production evolved as new technologies appeared to make it lighter. Tables and cupboard doors were produced from boards of 2-2.5 cm thick. Then new techniques were developed to produce lighter boards by reversely placing each sheet of wood layers from lighter trees such as pine or spruce, a technique still used today. These were manufactured with a veneering of walnut or oak by the Machine and Chemistry Industry of Turkey. Due to the lack of technology, they were pressed using bench clamps while the primitive state of planers and the lack of technological development meant that production was mostly done manually. ${ }^{17}$

While wood manufacturing processes and technology did not develop during this period, there was a considerable evolution of metalwork in Turkish furniture. As Yıldırım Kocacıklığlu, co-founder of Interno furniture and interiors firm (1962) noted, "There was no change in wooden furniture. Therefore, there were always good artisans. Development was mostly in metal. Metal furniture was not very easy. Bending wood was very difficult and there were special tools for that. Therefore, it was very primitive at first. Since they were not manufactured due to the lack of factories; they were all crafted in workshops. ${ }^{18}$ According to Irmak, metal furniture became widespread in Turkey during the 1960s, mostly for offices, since metal sheets were cheaper and could be mass produced. Companies like Masis and Arma emerged as the first mass producers. However, wooden furniture was still in demand for the offices of higher social class customers in higher business positions. ${ }^{19}$ It is also important to mention Metal Mobilya (Metal Furniture) (1959). Mustafa Plevne, the founder and owner of the firm, explained its name: "I did all kinds of metal work, yellow brass, stainless steel, iron, tilt, zinc; all kinds except for gold and silver ... Silver plating, gold plating ... these were also done. That is why the company's name is Metal Furniture". ${ }^{20}$ However, Turkey's aluminium industry was not yet mature enough then. In particular, factories added extra lead to soften the aluminium. As Önder Küçükerman, an interior architect and scholar, states:

15 Sadık Aktar, interview by authors, February 17, 2014.

16 Mehmet İrfan Dolgun, interview by authors, September 2, 2013.

17 Irmak, interview.

18 Yıldırım Kocacıklığlu, interview by authors, October 10, 2013.

19 Irmak, interview.

20 Mustafa Plevne, interview by authors, October 22, 2013. 
"When Sadun (Ersin) wanted to make chairs for our new restaurant in the Academy, he produced the first aluminium pipes. It was not meant to be used for chairs, but we liked to use different materials for different furniture. They manufactured chairs using this aluminium and wood. However, the aluminium was very soft then as there was no duraluminium yet. The legs of those chairs were bending, and Ahmet Efendi, the staff member working in the school restaurant, tried to fix their legs every day. Later we saw harder aluminium, but there were no fittings or connectors. For example, I had to manufacture my own furniture when I got married. For that furniture, I ordered special sections from Profilo, yet those cost more than the whole furniture. I drew all the pieces one by one by myself. There were no materials then, so it was a terrible time until industrial manufacturing started." 21

As plastic injection moulding technology emerged, the use of plastics, "ubiquitous in modern life" as a "principal material in a range of artefacts found in the home, as leisure equipment and in industry" 22 spread internationally in the mid-twentieth century. Pieces by prominent designers, such as Joe Columbo's plastic chair (produced by Kartell, 1968) or Verner Panton's stacking chair (produced by Henry Miller, 1967), encouraged such products in the late 1960s. This process involved making alternative forms in furniture making. Laminated products emerged in the 1960s, mostly for office spaces, as in the famous example of Action Office by Robert Propst and George Nelson. This glossy material provided optimum steady, smooth surfaces for work that were easy to clean hygienically. This made them preferred for kitchen use and table cabinets, soon resulting in the brand Formica that produced "formica laminate" as "one of the first laminates" 23 . Its use for surfaces expanded after the Second World War, and it was also combined with plywood, such as Alvar Aalto's stools and tables in the $1960 \mathrm{~s}^{24}$

Production of Formica which was followed by flake boards heralded the progress of the furniture sector in Turkey, introducing and widening the use of engineered wood. Formica soon became popular in Turkey (Figure 1), as Babür Kerim İnceday1, an interior architect and scholar, recalled: "A new material called 'Formica' was introduced in Turkey, and it was the first example of modern furniture in Turkey. It was plain, easy to mount and easy to produce; it was also cheap. Later it became kitsch but was complemented with other materials". ${ }^{25}$ As Adem Y1lmaz, the founder and owner of Delta Mobilya (Delta Furniture) (1972) stated, the Aksa Group later produced For-

21 Önder Küçükerman, interview by authors, December 18, 2013.

22 John Coles and Naomi House, The Fundamentals of Interior Architecture (West Sussex: AVA Publishing, 2007), 114.

23 Anthony Sully, Interior Design: Conceptual Basis (Heidelberg, New York, Dordrecht, London: Springer International Publishing, 2015), 143.

24 David Raizman, A History of Modern Design: Graphics and Products since the Industrial Revolution (London: Laurence King, 2004), 333.

25 Babür Kerim İnceday1, interview by authors, January 28, 2014. 
mica where Kelebek was first established, and panels or chipboard. These products helped the industry develop ${ }^{26}$, as Irmak, an interior architect and scholar, explained:

“A composite resin-based material emerged, called by the firm's name Formica. It gained momentum since it was ready for use without coating or polish. Especially, they were popular as tabletops or surfaces, became familiar with tables used by civil servants. In parallel, round cut metal termed 'pipe profile' and square sections ... as mass manufacturing developed, manufacture of furniture with simple lines without many details was mostly preferred." 27
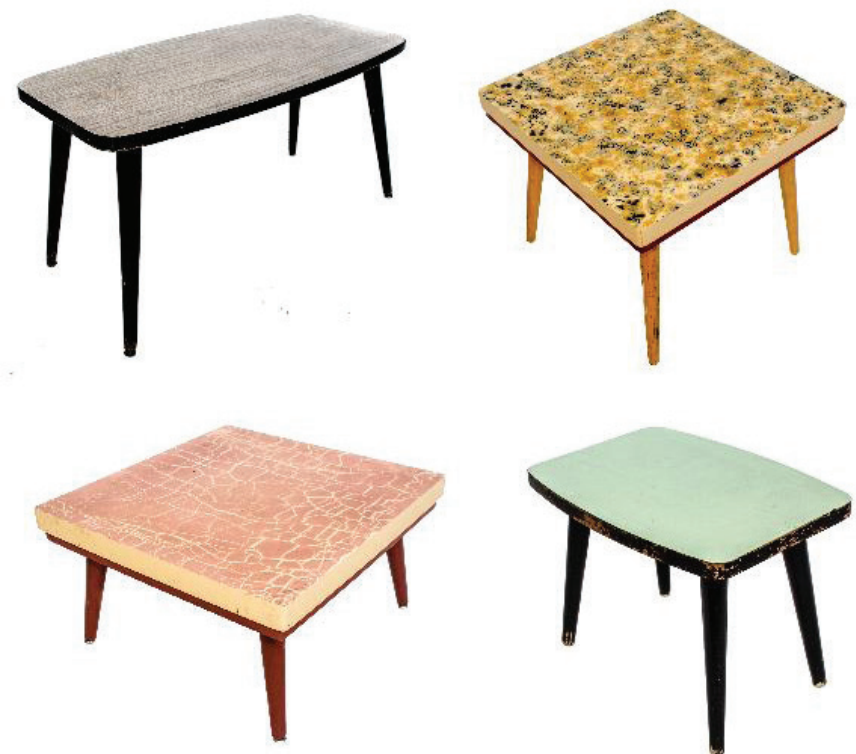

F.1: SIM Mobilya Coffee Tables with a Formica Tabletop, S2, 1959-72 (CDATUMM archive: www.datumm.org)

As stated by Döll, "unconventional materials may have an inspiring effect" "as they help to push the boundaries of material options" ${ }^{28}$. Creative materials were also used, such as wire netting, brass plating, water pipes, electric cables and nut sieves. For example, Erol Ata, the son of Metin Atabey Ata, the founder/owner of ERSA Mobilya (1958), described a model called "Bulgar Somya", made from wire netting. The firm also manufactured bedsteads with brass plating..$^{29}$ Neptün Öziş, the son of Sadi Öziş, artist and the co-founder of Kare Metal Firm (1955-1966), explained several other creative material solutions that the firm found to offset the lack of materials (Figure 2):

26 Adem Y1lmaz, interview by authors, January 29, 2014.

27 Irmak, interview.

28 Döll 2002 as quoted in George Verghese, "Sensual Spaces Through Material Abstraction,” Thinking Inside The Box (London: Middlesex University, 2007), 200.

29 Ata, interview. 
"Additionally, let us say, they find power cables; they use them for tiling. Then they notice this does not create a rebound and take out the wire and use only the plastic part ... They want to use perforated sheets, but again it is not possible to find these. Therefore, they consider what is available. They see nut sieves, and consider these for use. They see that they have fishing nets available, so they start to think about how to use fishing nets in furniture. They weave the fishing net into the metal frame to create a chair..." ${ }^{30}$
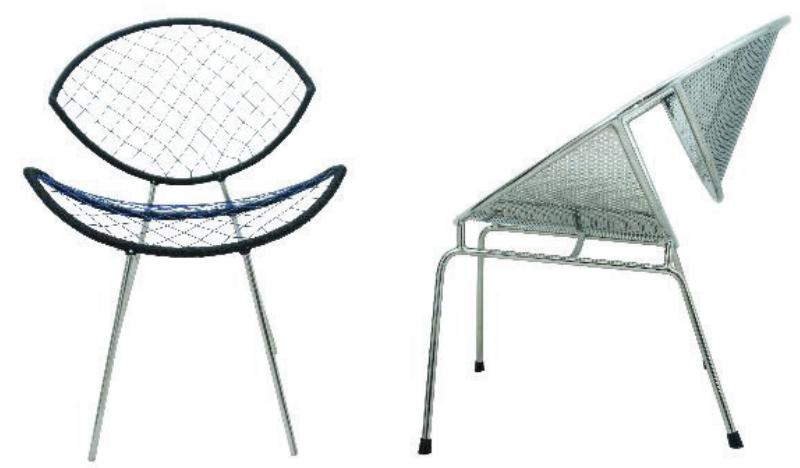

F. 2: Reproduced Kare Metal Furniture Under Karre Label Showing the Use of Creative Materials such as Fishing Net or Nut Sieve (CDATUMM archive, www.datumm.org)

While acknowledging how advanced today's production has become by using robotic technologies, Ata recalls enjoying the creative problem solving back then due to the lack of materials and know-how: "Cutting barrels into metal sheets with hand shears or manual scissors, making primitive bends with oxygen sources (...) using totally unrelated materials, such as water pipes, or primitive methods of coating and colouring. It was difficult but enjoyable to find alternative solutions". ${ }^{31}$ Because of this, they used materials like water pipes in the 1960s in roll form machines to produce square sections, which were otherwise unavailable. Heating pipes were preferred for their durability whereas lead water pipes were not allowed in furniture production. Küçükerman commented on the use of pipes:

"They were thick and heavy, and worse, we could not weld them. In the third year of our studies, we heard that rolled-steel section pipes had emerged. I wanted to see the place where those were made, so I went to Karaköy, İstanbul. There was a man making them one by one with significant effort. However, they were never exactly square-shaped; therefore, they applied putty, and shaped it again. After the emergence of square pipes in 1965, square sections emerged over the following 30-40 years to significantly change furniture manufacturing in Turkey." ${ }^{32}$

30 Neptün Öziş, interview by authors, December 16, 2013. Özkaraman Şen also quotes Sadi Öziş stating the creative use of different materials stemming from the poverty of the period. Özkaraman Şen, "Türkiye'de 1800-2004 Yılları Arasındaki Değişim Süreci İçinde Tasarımı Etkileyen Faktörler: Ve Bir Örnek Olarak Mobilya Üretimi Modeli," 167.

31 Ata, interview.

32 Küçükerman, interview. 


\subsection{Production Technologies}

Production methods were still primitive in Turkey in the mid-century, relying on manual techniques in small workshops that depended on the abilities of the crafter and the available material. These workshops were mostly organised in a master-apprentice relationship, in which training was delivered through hands-on experience. A majority of crafters were non-Muslims and the first to train future producers. ${ }^{33}$ The limited expertise and supplies demanded creative solutions, so the quality of the furniture produced then mostly depended on artisanship. ${ }^{34}$ Öziş also mentioned the importance of crafters, adding that his father regarded each piece as an artwork, carefully produced by hand and bound with emotions. His background in Fine Arts must have initiated such a dialogue with production:

"Actually, he [Sadi Öziş] has never been a manufacturer dependent on technological devices. It was clear that his Fine Arts background brought emotion even in the production phases of furniture. He tried to work with basic devices with the technology of the time, but he tried to create pieces where handwork was more prominent. In our workshop, I remember the artisans of that time very well; we worked with artisans with 20 to 30 years of experience ... He always emphasised that these furniture pieces were only possible because of the artisans' love and emotion. That is why he never aimed to progress in the fields of $\mathrm{CNC}$ devices or exceptional machines. They could buy a new version of the same machine, but they would always continue with more primitive techniques." ${ }^{\text {35 }}$

İncedayı also explained the reliance on artisanship: "There were no integrated systems in those years. There were no modular kitchen factories or factories doing serial production or integrated facilities in Turkey. There were small ateliers based on the master-apprentice relationship. In the 1960s, there were no firms producing windows or office furniture like today. In those years, awareness had just started." ${ }^{36}$ Even hinges and profiles were produced manually. For example, Sadun Ersin recalled that hinge production was customised, which he called 'coupon hinges', referring to their quality. For many types of hinges, he first saw them in Italy before manufacturing similar ones in Turkey. The variety in production only expanded after the opening of large department stores ${ }^{37}$ Küçükerman also recalled that aluminium connections were hand-made and even the screws, which were designed individually:

33 Durmuş, "Türkiye'de Modern Mobilyanın Gelişimi," 28; and Özkaraman Şen, "Türkiye'de 1800-2004 Yı1ları Arasındaki Değişim Süreci İçinde Tasarımı Etkileyen Faktörler: Ve Bir Örnek Olarak Mobilya Üretimi Modeli," 294. Durmuş and Özkaraman Şen portray non-Muslim furniture producers from late Ottoman period to mid-century.

34 For a wider discussion about the relationship of design-designer and artisanship, please see İrem Senemoğlu, "Mobilya Tasarımında Tasarım ve Zanaat İlişkisi Üzerinden Kültürel Sürdürülebilirlik ve Türkiye'de Durum" (M.A. thesis, Mimar Sinan Fine Arts University, 2019).

35 Öziş, interview.

36 İncedayı, interview.

37 Neptün Öziş, interview. 
"Thousands of [screws] are sold in hardware shops nowadays, but back then, there were none. I still keep my drawings; I designed them carefully: how they would be made; how they would be squeezed, since there was no wrench to do it. Because it may come loose, you had to tighten the screw. Therefore, before industrial production the raw materials field was a total disaster." ${ }^{38}$

Under these conditions, the first department store was a huge surprise while manufacturing interiors and furniture pieces was full of difficulties:

"If we could manufacture L sections, we could make armchairs, chairs or bedsteads us-
ing them. However, had neither. First, we went to Borusan [a major pipe manufacturer];
however, they said they could not manufacture our sections, as they needed too much
power to make. We were disappointed, and while we were in Şişhane, İstanbul, I saw a
bedstead maker, and he said he could make it, as it was a simple thing to do. He thought
he would just make some iron sections, but I said we would build a huge skyscraper in
Ankara, and if he would make this section, the whole job would be his. We were sur-
prised since he made a really good section. We asked how he did it; he would not tell us
as it was his secret. He said he had migrated from Yugoslavia, and he was working in a
plane factory producing plane parts. Thanks to our project, he enlarged his business. For
wood production, Ali İhsan Şark helped us. Those people became prominent industrial
furniture manufacturers in Turkey." 39

Mass production was one of the most important issues. As Turkish apprentices grew to be journeyman, they started running the workshops. Production thus remained handmade or individual. Irmak recalled that Turkish mass production began with metal furniture while Aktar named Moderno was one of the leading companies that shifted to mass production, particularly through the development of new machinery:

"The first hydraulic pressing machines and many other new things were brought there [Moderno] for the first time in Turkey, and mass manufacturing started. However, this was the second style of Moderno; before that, there was a store in which lighting systems were also exhibited, and its showcase was once every two weeks, which people would impatiently wait to see. Later, in the second phase of Moderno, the store moved to another district in İstanbul, Harbiye, to a four or five-floor building in which one floor was reserved for design. The other floors were showrooms. This was the time when Moderno started mass manufacturing. Later, in 1967, furniture manufacturing in Moderno ended." ${ }^{40}$

38 Küçükerman, interview.

39 Küçükerman, interview.

40 Aktar, interview. 
Another important Turkish firm was Masis. It triggered production changes in both machinery and business management, as Yilmaz noted:

"For the Turkish metal industry, Masis succeeded in producing modern furniture with presses brought from Germany and so pioneered modern furniture production using metal. In addition, following in their footsteps, Korçelik and other brands paved the way. Masis Balyan entered into the business by producing the first bed base, and sent them to Anatolia by train. He created an environment where others would aspire to apply this high technology to furniture." ${ }^{41}$

On the other hand, for those who still produced by hand, the techniques that were used then still exist today. As Artun Boyaciyan, the son of Minas Boyaciyan, the founder of Minas Mobilya (1945), stated: "We have our manufacturing conditions that we used for a long time and we still use. Those are machines and machinery that we established, and they still exist; however, we did not use them for mass production. The manufacturing techniques and machinery we use now are very similar to the ones that were used by our father." ${ }^{\text {"42 }}$ In the historiography of furniture, furniture joinery is generally secondary to formal and material issues. ${ }^{43}$ However, the interviewees also mentioned joinery technologies. For example, Dolgun talked about his rapid technique for drying and manufacturing dowels, which for a key factor in the durability of his furniture.

According to Öziş, welding was not used much because metal production was not advanced and materials were scarce, so furniture production mostly depended on wood. ${ }^{44}$ Ersin explained the initial experiments in metal in the Academy of Fine Arts:

"Since the Academy had a small budget, we said, 'We can do it' as the department of sculpture. We created a stool design and made hundreds of them. All the student cafeteria furniture was made like this (...) We were not dealing with glue or joints. They were all screwed. Everything modular. Iron legs were cut in the sculpture workshop, which pierced all the holes for us appropriately." 45

Ata recalled mostly using clout nails on armchairs instead of sewing. In addition, because there were no special machines for driving in nails, they fixed them individually by hand. ${ }^{46}$ Gluing was another important component in the joining process.

41 Yilmaz, interview.

42 Artun Boyaciyan, "Mid-Century Modern Furniture Design and Production in Turkey," interview by authors, October 21, 2013.

43 Mark Hinchman, History of Furniture. A Global View (New York: Fairchild Books, 2009).

44 Öziş, interview.

45 Ersin, interview.

46 Ata, Inter interview. 
Glues resembling fish oil -yellow and beaded- were particularly effective. ${ }^{47}$ Boyaciyan described gluing techniques and processes in more detail:

"We continued to use hot glue, and we still have some pieces in which we use it. Apart from this, we also used a special covering made by combining hot glue with hammered inlay on cambered surfaces and especially on marquetry. Apart from this, we used Shellac and we still use it; it was done by filling the pores in layers. New materials came onto the market; first polyester and then cellulose products. While cellulose is still used, with the advance of various component materials imported from other countries, it is not that popular. Of course, materials change; nonetheless, the only thing that does not change is mastery." ${ }^{48}$

The whole process from production drawings to the control of manufacturing processes had to be designed meticulously. Detailed drawings were necessary, as Cansel noted regarding production drawings: "He [Danyal Çiper] would blueprint everything down to the screws; he would also blueprint which type and which size of shear connectors would be used and designed according to it" (F. 3). ${ }^{49}$ Erol Ata's father, Metin Atabey Ata, used to oversee the manufacturing process (F. 4):

"Especially when a new product would be manufactured, he would put on his overalls and work from morning to evening during the process, starting with the preparation of the prototype until its mass production. He shaped the production, enabled mass production, determined patterns and supervised the whole process. Until the last 3-4 years, he kept doing this". ${ }^{50}$
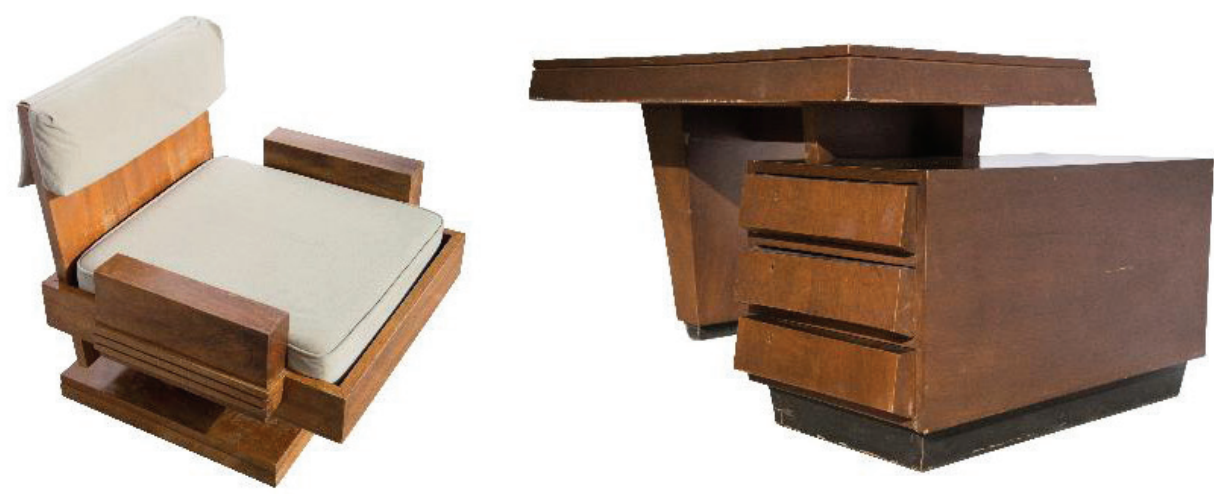

F. 3: Furniture by Danyal Çiper, Showing Creativity in Form and Connections

(CDATUMM archive, www.datumm.org)

47 Irmak, interview.

48 Boyaciyan, interview.

49 Cansel, interview.

50 Ata, interview. 

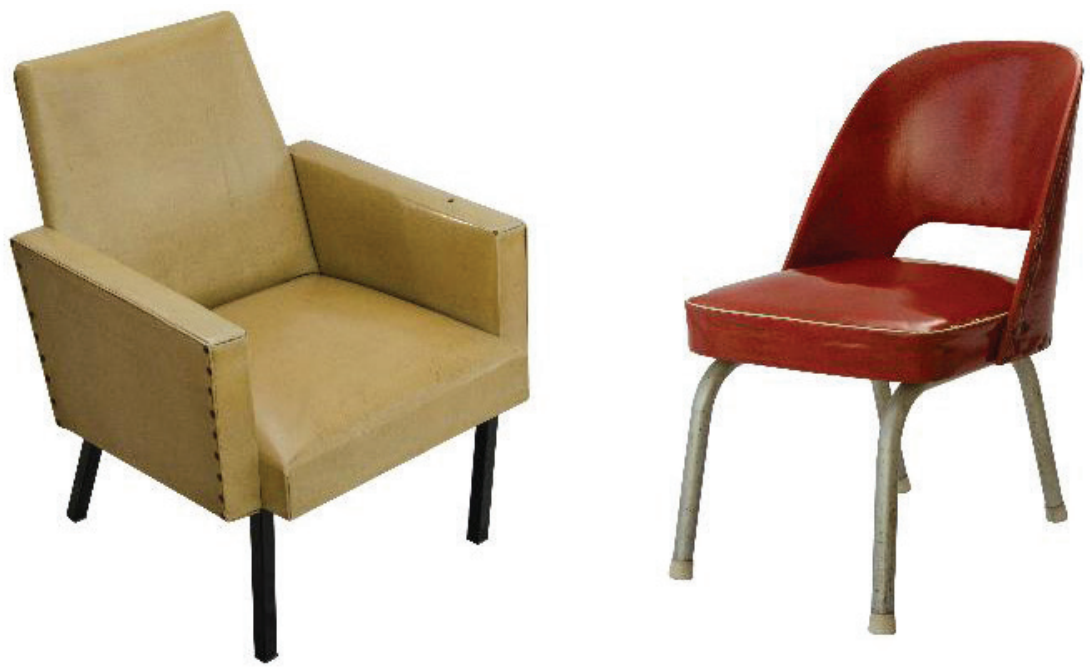

F. 4: Chairs by ERSA, Showing New Geometric Forms and Creative Use of Materials such as Water Pipes (CDATUMM archive, www.datumm.org)

Integration of designers or manufacturers in production was a valuable method in those days to develop oneself and handle difficulties (F. 5). Plevne offers the following insight on this: "I needed to study a lot about chemistry, chemistry is quite important in chrome works. Many people learned from their fathers or someone else and do it just the same, did not improve themselves. I always studied since my job required me to do so." ${ }^{51}$
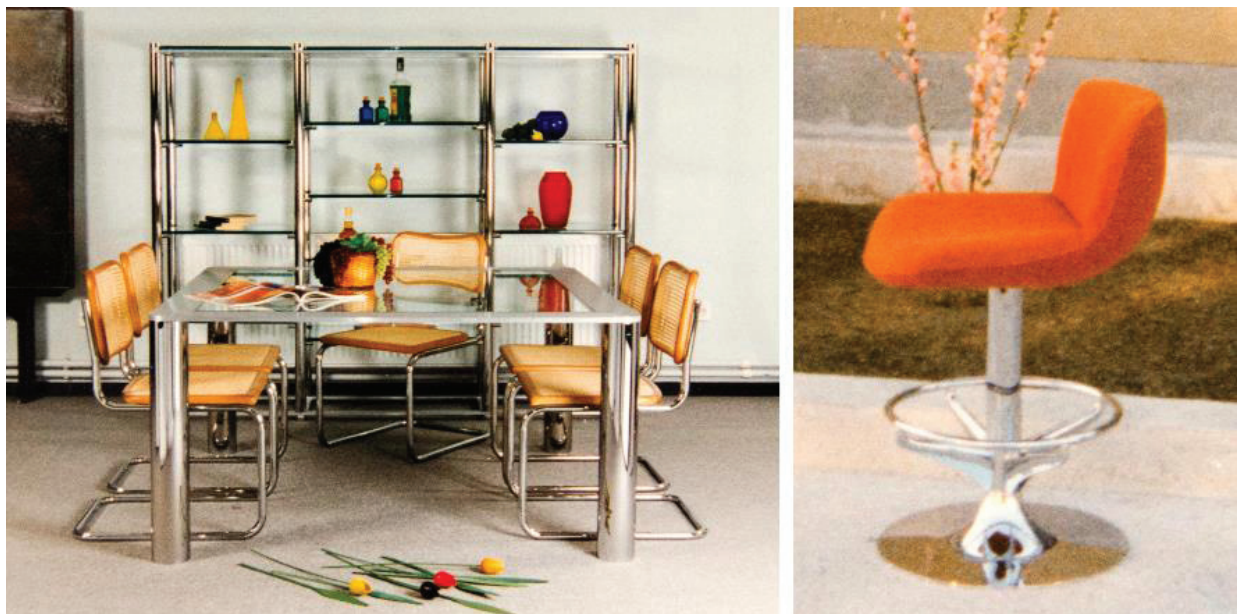

F. 5: Furniture by Metal Mobilya, Showing Use of New Materials such as Chrome (CDATUMM archive, www.datumm.org) 


\subsection{Difficulties}

Difficulties resulted from various limitations in materials, technology, literary resources, production space and personnel. Küçükerman provided an anecdote exemplifying the search for material resources:

"During our studies, the most important subject was wood and technology used with wood. When we first encountered iron, the most important problem was that we could not weld or bend it. We used very primitive methods like putting sand into it and heating the sand to bend the iron pipes. It was also a very hard and time-consuming technique, so people would take good care of their furniture. ${ }^{52}$

Materials to support or give form to furniture, such as sponge, were not produced in mid-twentieth-century Turkey: "Rubber sponge was newly introduced. That rubber sponge made it easier to produce, so everybody started producing." 53 In the absence of sponge, straw was the answer, as Ata explained: "Since we did not have enough sponge, we sometimes filled armchairs by using straw and different plants. Those were enjoyable and enabled us to be creative. Since we had to use alternative materials, we used trial and error so many times to find the right material. ${ }^{54}$ Dolgun talked about another specific limitation: "I could not manufacture some things like metal springs. IDAŞ was manufacturing them, but their springs were for beds and were too thin for armchairs. I looked for solutions for this like merging two springs together to create a thicker one." ${ }^{55}$ Other material limitations were fabrics, metal alternatives, lighting fixtures and accessories. Bediz Koz, the founder/co-owner of the interiors firm Butik A (1959), identified the following limitations:

"We did not have good fabric; therefore, we used coat fabric for our furniture. We mostly used leather, and I liked it a lot. We once made a sofa like patchwork by using some leather pieces, which remained from our previous work ... Since we did not have enough materials, we used chrome with iron instead of steel; naturally, however steel is used now ... Once we made lamps using metal since we did not have any accessories. An architect friend, Erkal, made saltshakers from wood and we presented them to people ... In addition, hinges and handles were unavailable, so we got them manufactured." ${ }^{16}$

Designers were also hindered by technological limitations: "Because of the limited level of technology, we had to work in very primitive conditions both in terms of materials and production techniques; nonetheless, since our rivals had the same problems too, this was not such a big problem. ${ }^{57}$ Ata further explains the lack of machines:

52 Küçükerman, interview.

53 Dolgun, interview.

54 Ata, interview.

55 Dolgun, interview.

$56 \mathrm{Koz}$, interview by authors, November 26, 2013.

57 Ata, interview. 
"Though technology was developing, we did not have enough machinery or raw materials; imports were not allowed either. Even if it were allowed, as there were not enough resources in Turkey, we could not import so much. (...) Our time was very different from now in terms of technology; we produced good things though. As we could sell everything we manufactured, we did not look for a change or new designs. ${ }^{58}$

There was also a lack of literature at that time, for example regarding ergonomics. Consequently, as Öziş states, there was mostly a trial and error process with designers measuring their own bodies to solve ergonomic problems:

"They sat on sand, and drew the proportions of their body to measure. They did this with different people since people had different heights; for example, my father was short, but Şadi Çalık was very tall. They both sat on sand, and they thought about how they could make furniture appropriate for both of them. They started with these primitive resources. ${ }^{\circ 5}$

Finally, there were limitations regarding personnel and production spaces. The manufacturing process was very slow since they worked in ateliers with one or two artisans ${ }^{60}$ while the spatial conditions of manufacturing also affected production quality. As Ata recalled, "The products we made were on the roof of our dye house on the third floor. We would lift the furniture up through a one-meter-wide hatch with a primitive ladder, and then paint it there, in the garret. Then it would dry outdoors". ${ }^{61}$ Similarly, Aktar described the spatial conditions of Moderno's production space:

"The first productions of Moderno were in a small-scale place in comparison to today's norms. There was a place behind Moderno, and everything was made there manually. There were pressing machines and large caldrons in which glue was always boiling. They were used during the manufacturing process. There was a material called "duralit", which was like cardboard, and there was plyboard. Except for these, everything was being produced in this small workshop. Later, Moderno started to sell its products not only in Istanbul but also everywhere in Turkey. As Moderno started mass production, it moved to Bomonti in İstanbul, to a medium or large-scale factory." ${ }^{\prime 2}$

\section{Conclusion}

To conclude, analysing the materiality of a product allows the micro history of design to be read in relation to developments in a country's economic, cultural and social situation. Moreover, understanding the material qualities of a furniture piece produces 
an analysis based not just on mere forms or styles but also on cultural productions. These tell the story of a country's efforts to develop and thrive. Grasping the extent of limitations in materials, expertise or technology makes the reading of furniture valuable since the evolution of furniture depends on these aspects, more than a simple search of accepted forms. It is important also to acknowledge which materials were accepted by the public, such as the use of wood for a long time as a sign of cultural status, since furniture is closely bound to the daily environment.

The development of materials and technology had profound impacts on shaping furniture. Together with this, cultural shifts, emergence of new spatial typologies, commercial spaces and the vast amount of furniture they required surely altered the perception of furniture. Furniture's meaning inside domestic space as a "one of a kind" crafted item to pass on for generations, transformed into a consumer good for the changing market of the 1950s. This had a drastic effect on the relationship between a space, its furniture and the habits of experiencing both. The ephemerality of modern spaces required stand alone, lighter, more durable and mass-produced furniture, quite in contrast with previous understanding of built in furniture of a traditional Turkish house. This meant a complete alteration of inhabiting and building an interior. This shift was reflected on the spatial layout and furniture used in public interiors as well, such as banks, offices, and new spaces that were introduced with modernity, such as supermarkets.

Inevitably with mass production and changes of consumption and inhabitance, furniture started to be considered as a design object tackled by designer or architects rather than a generation of craftsmen. For the case of Turkey, it is also possible to state that, it became a new field for designers, which was probably non-existent. Maybe for this reason, the first experiments in metal furniture were conducted by artists, which highlight the importance of materials and know-how. Drawn from the interviews, the first experiments of furniture, which somehow resided in between mass and artisanal production, gave way to fruitful results of artistic expression. From this perspective, the study of materials conveys also designer's/architect's changing role and development of design professions in mid-century Turkey.

The story presented here of the three categories of materials, natural, synthetic and creative, both explains their distinct uses and highlights the designers, manufacturers and companies that were established at this time but not previously documented. In addition to this contribution to Turkish design history, this study reveals the evolution of materials and manufacturing techniques. Moreover, by connecting the stories to specific pieces of furniture, furniture can be documented not just as an artefact but also as a final product of an assemblage of people, materials and techniques. Without these personal accounts of how modern furniture developed in Turkey, accessed through oral history, it would not have been possible to achieve this outcome. 
The oral history reported here adds significantly to knowledge about modern furniture in Turkey. Indeed, current knowledge is limited - or almost limited regarding materials. The story of the materials used in modern furniture enabled the documentation of the materials and production techniques unique to Turkey. This study explained the transformation from traditional ways of making wooden furniture towards new materials and techniques as a means of cultural and material modernisation in mid-twentieth-century Turkey. Using primitive methods and limited materials, Turkish designers tried to manufacture furniture with what they had. These limitations paved the way for an industry to grow and learn from these experiments. These efforts can thus be read as ways of adapting to the world order and joining the international arena through the development of the materiality of modern furniture in Turkey.

\footnotetext{
Hakem Değerlendirmesi: Dış bağımsız.

Çıkar Çatışması: Yazarlar çıkar çatışması bildirmemiştir.

Finansal Destek: Bu makale, İzmir Ekonomi Üniversitesi bilimsel bir araştırma projesitarafindan finanse edilen DATUMM: Dokümantasyon ve Arşivleme Türk Modern Mobilyaları kapsamında desteklenmiştir. Proje numarası: A1308001 / BAP-A024-K. Teşekkür: Yazarlar ayrıca röportajların video editörü olan Ali İnceoğlu'na ve projede röportaj yapan Seren Borvalı'ya teşekkür etmektedirler.

Peer-review: Externally peer-reviewed.

Conflict of Interest: The authors have no conflict of interest to declare.

Grant Support: The content of this article was produced by the authors, within the DATUMM: Documentation and Archiving Turkish Modern Furniture, which is a scientific research project funded by the İzmir University of Economics, project number: A1308001/BAP-A024-K.

Acknowledgement: Authors would also like thank Ali İnceoğlu, the video editor of the interviews, and Seren Borvalı, one of the interviewers in the project.
}

\section{References/Kaynakça}

Arslan Dinçay, Demet. “İç Mekân Tasarımında Malzeme ve Mekânda Anlam İlişkisi” Accessed 14 April 2020. https://yapidergisi.com/ic-mekan-tasarimininda-malzeme-ve-mekanda-anlamiliskisi/

Boyla, Oya. "Mobilya”. Eczacıbaşı Sanat Ansiklopedisi. İstanbul: YEM Yayınları, 1997, 1285-1286.

Coles, John and Naomi House. The Fundamentals of Interior Architecture. West Sussex: AVA Publishing, 2007.

Durmuş, Serpil. “Türkiye'de Modern Mobilyanın Gelişimi.” M.A. thesis, Marmara University, 2005.

Gagg, Russel. İç Mimarlıkta Doku+Malzeme. İstanbul: Literatür Yayınları, 2012.

Hinchman, Mark. History of Furniture. A Global View. New York: Fairchild Books, 2009.

Lefteri, Chris. "Traditional Materials.” Designing Interior Architecture. Basel: Birkhauser Verlag $\mathrm{GmbH}, 2013,157-175$.

"Materiality." Accessed 19 September 2020, https://www.merriam-webster.com/dictionary/ materiality.

Nielson, Karla and David Taylor. Interiors. New York: McGraw-Hill Education, 2006. 
Özkaraman Şen, Meltem. “Türkiye'de 1800-2004 Yılları Arasındaki Değişim Süreci İçinde Tasarımı Etkileyen Faktörler: Ve Bir Örnek Olarak Mobilya Üretimi Modeli.” PhD. dissertation, Mimar Sinan Fine Arts University, 2004.

Pek, Shun Ping. "Exploration of Materiality in Furniture Design.” Accessed 14 April 2020. https:// dr.ntu.edu.sg/handle/10356/63316.

Raizman, David. A History of Modern Design: Graphics and Products since the Industrial Revolution. London: Laurence King, 2004.

Schröpfer, Thomas. Material Design: Informing Architecture by Materiality. Basel: Birkhäuser, 2011.

Senemoğlu, İrem. "Mobilya Tasarımında Tasarım ve Zanaat İlişkisi Üzerinden Kültürel Sürdürülebilirlik ve Türkiye'de Durum.” M.A. thesis, Mimar Sinan Fine Arts University, 2019.

Sully, Anthony. Interior Design: Conceptual Basis. Heidelberg, New York, Dordrecht, London: Springer International Publishing, 2015.

Uzunarslan, Şebnem. "Cumhuriyetin İlk Yirmi Yılında Mimarlık Alanındaki Gelişmelerin Mekân ve Mobilyaya Yansımaları,” Cumhuriyetin Mekanları / Zamanları / Insanlart. Ankara: Dipnot Yayınlar1, 2010, 169-186.

Verghese, George. “Architectural Heritage: Providing a Sense of Place Material Matters in a Modern Interior.” Paper presented at An Interdisciplinary Conference on Issues of Design Education, Business and Material Culture, Toronto, October 12-15, 2005.

Verghese, George. "Sensual Spaces Through Material Abstraction”, Thinking Inside The Box. London: Middlesex University, 2007, 197-206.

\section{Interviews}

I: 1: Adem Y1lmaz, born in 1953, university graduate, businessman.

I: 2: Ar1l Cansel, born in 1962, Assoc. Prof. Dr. of Marketing, faculty member.

I: 3: Artun Boyaciyan, born in 1975, university graduate, product designer.

I: 4: Babür Kerim İnceday1, born in 1945, university graduate, interior architect.

I: 5: Bediz Koz, born in 1936, university graduate, interior architect.

I: 6: Erol Ata, born in 1953, university graduate, businessman.

I: 7: Mehmet İrfan Dolgun born in 1928 (d.2019), furniture artisan.

I: 8: Mustafa Plevne, born in 1930, furniture artisan.

I: 9: Neptün Öziş, born in 1970, architect, yacht designer, furniture designer.

I: 10: Önder Küçükerman, born in 1939, professor, interior architect.

I: 11: Sadık Aktar, university graduate, architect.

I: 12: Sadun Ersin, born in 1930, professor, interior architect and artist.

I: 13: Yavuz Irmak, born in 1950, university graduate, interior architect.

I: 14: Y1ldırım Kocacıklığlu, born in 1937 (d. 2015), university graduate, interior architect. 
